\title{
Effect of the supplementation linseed oil, inulin and horse chestnut into a high fat diet on the fatty acid profile of pigs
}

\author{
O efeito de óleo de linhaça, inulina e castanha da Índia sobre o perfil dos \\ ácidos graxos nos suínos após adição de uma dieta rica em gordura
}

\author{
Matej Brestenský ${ }^{*}$ Soňa Nitrayová ${ }^{I}$ Peter Patráš ${ }^{I}$ \\ Jaroslav Heger ${ }^{I}$ Jozef Nitray ${ }^{I I}$
}

\section{ABSTRACT}

In the present study it was evaluated the effect of the addition of linseed oil, inulin and horse chestnut added to a high fat (HF) diet on the content of fatty acids (FAs) in musculuss longissimus dorsi (MLD) of pigs. A $5 d$ with adaptation period was followed by a $70 \mathrm{~d}$ experimental period, during which the pigs were fed with a HF basal diet. The HF basal diet which served as a control (group CG) was supplemented either with linseed oil (group $L G$ ) or with inulin and horse chestnut (group IG). All of the pigs were slaughtered at the end of the experiment and samples of $M L D$ were taken for FA analysis. The concentration of $\alpha$-linolenic acid in MLD of the LG group was $58 \%$ and $61 \%$ higher $(P<0.05)$ compared to $C G$ and $I G$ groups, respectively. The content of eicosapentaenoic acid (EPA) was 0.03 and docosahexaenoic acid (DHA) 0.07 in LG treatment. These FAs were not detected in $C G$ and IG. The ratio of MUFA and PUFA n-6/n-3 in the MLD was the lowest $(P<0.05)$ in the $L G$ (8.84) compared to $C G$ (14.07) or IG (14.74) groups, representing a difference of $31.2 \%$. The $n-3 /$ saturated FA ratio was highest $(P<0.05)$ in LG group (0.04) when compared to $C G$ and $I G$ groups (0.02). The supplementation of linseed oil, into the HF diet resulted in a higher concentration of $\alpha$-linolenic acid, EPA, DHA and lower ratio of n-6/n-3 FA in MLD. Inulin and horse chestnut had no effect on FA profile of MLD.

Key words: diet, fatty acid, linseed oil, pig, prebiotics.

RESUMO

No presente estudo, avaliamos o efeito de óleo de linhaça, inulina e castanha da Índia sobre os conteúdos dos ácidos graxos dos musculuss longissimus dorsi (MLD) de de suínos, após receberem uma dieta rica em gordura. Depois de um período de adaptação de 5 dias, seguiu-se um período experimental de 70 dias, durante o qual os suinos foram alimentados com uma dieta rica em gordura. A dieta rica em gordura, que serviu como controle (grupo CG), foi suplementada com óleo de linhaça para um grupo ( $L G)$, e ainda com inulina e castanha da Índia para outro grupo (IG). Todos os animais foram abatidos no final do período de experimentação, sendo que amostras de MLD acabaram por ser recolhidas de forma a analisar a concentração de ácidos graxos. A concentração do ácido $\alpha$-linoleico nos $M L D$ do grupo $L G$ foi $58 \%$ e $61 \%$ superior $(P<0,05)$ quando comparada aos grupos $C G$ e $I G$, respectivamente. A concentração do ácido eicosapentaenoic (EPA) foi de 0,03, enquanto a do ácido docosahexaenoic (DHA) foi de 0,07 no grupo LG. Esses ácidos graxos não foram detectados nos grupos $C G$ e $I G$. A relação de MUFA e PUFA n-6/n-3 nos MLD foi mais baixo $(P<0,05)$ para o grupo $L G(8,84)$, quando comparado com o grupo $C G(14,07)$ ou $I G(14,74)$, representando uma diferença de $31,2 \%$. A relação de $n$-3/ácidos graxos saturados foi maior $(P<0,05)$ para o grupo $L G(0,04)$, quando comparado com os grupos CG e IG $(0,02)$. A suplementação de óleo de linhaça na dieta rica em gordura dos animais resultou numa maior concentração de ácido $\alpha$-linoleico, EPA, DHA e ainda em uma relação mais baixa de $n-6 / n-3$ de ácidos graxos nos MLD. Inulina e castanha da Índia não tiveram efeito no perfil de ácidos graxos dos MLD.

Palavras-chave: dieta, ácidos graxos, óleo de linhaça, suínos, pré-bióticos.

\section{INTRODUCTION}

Fat is an important component of a diet, but in Western-type diets, the intake of saturated fatty acids (SFA) is higher in proportion to unsaturated fatty acids (UFA), and the total proportion of fatty acid (FA) intake is unbalanced. The saturated FA content of the total dietary energy intake should not be higher than $10 \%$, and the content of monounsaturated fatty acids (MUFA) and polyunsaturated fatty acids (PUFA) should be up to $15 \%$ and $10 \%$ of the total

\footnotetext{
'Department of Nutrition, Research Institute of Animal Production Nitra, National Agricultural and Food Center, Hlohovecká 2, Lužianky, 951 41, Slovakia. E-mail: m_brestensky@vuzv.sk. "Corresponding author.

ITekmar Slovakia Company limited (Ltd.), Vinárska 26, Lužianky, Slovakia. 
daily energy intake. To achieve good body health conditions, the optimum ratio of FA n- $6 / n-3$ should be low (RUSSO, 2009). The main health effect of UFA is attributed to n-3 FA (SIMOPOULOS, 1991), $\alpha$ - linolenic acid and its metabolites eicosapentaenoic acid (EPA) and docosahexaenoic acid (DHA), which are essential for the body.

An increased content of UFA, particularly $\alpha$ - linolenic acid, in the diet has gained attention (WILLIARD, 2001). In case of humans, an increased UFA content can be achieved by increasing their contents in the consumed diet. The total content of n-3 PUFA increased in people who consumed meat from chickens fed with diets that were supplemented with linseed oil (HAUGH et al., 2012). Additionally, a linseed-supplemented diet had a positive effect on the FA composition from different adipose tissues (intramuscular and subcutaneous) in pigs. The FA composition of adipose and muscle tissues depends on diet, fat level, age and sex of the animals. Dietary FAs are incorporated into the adipose tissues of pigs without significant changes (BEE et al., 2008), and thus, the quality of the meat from monogastric animals can be easily affected by dietary manipulations.

Probiotics and prebiotics have favorable effects on the intestinal microflora. The intestinal microflora affects the lipid metabolism and modulates fat mass development in the body (WALL et al., 2009; DELZENNE et al., 2011), and therefore, it can be a dietary alternative that affects the content of FAs in a host tissue. Inulin-type fructans are considered prebiotics (ROBERFROID, 2007). Inulin, alone or in combination with horse chestnut, supports the growth of beneficial bacteria and reduces harmful bacteria in the gut and influences lipid metabolism in the host (LETEXIER et al., 2003; DEWULF et al., 2011; SZABADOSOVA et al, 2013).

In spite of the fact that prebiotics affect lipid metabolism, there is a little information about how these changes are reflected in the FA profile of muscles, and this effect was only studied in mice (DEWULF et al., 2011) or in chickens (VELASCO et al., 2010). Therefore, the objective of this study was to investigate the effect of linseed oil, inulin and horse chestnut added to a high fat (HF) diet fed to pigs on the content of FAs in the musculus Longissimus dorsi.

\section{MATERIALS AND METHODS}

A total of 18 gilts (Landrace $\mathrm{x}$ Slovak White; initial BW $25 \pm 0.5 \mathrm{~kg}$ ) were housed in balance cages. After a $5 \mathrm{~d}$ adaptation period, during which the pigs fed with a pig grower diet, there was a $70 \mathrm{~d}$ experimental period, during which the pigs received a basal HF diet supplemented with the tested substances. At the end of the experiment, the pigs were slaughtered, and the samples from the musculus Longissimus dorsi (MLD) were taken from the right half-carcass at the level of the last rib. The samples were frozen at $-20^{\circ} \mathrm{C}$ and stored for following analyses.

During the experiment, a basal HF diet with or without supplements was used (Table 1). A palm oil, containing a high content of SFA (FIORENTINI et al., 2015), which is responsible for negative alteration in the body (LAUGERETTE et al., 2015), was added to the diet in the amount of $13 \%$ to increase the content of fat in the diet. There were 3 experimental treatments: the control $(\mathrm{CG}, \mathrm{n}=6)$ was fed with the basal HF diet; the LG $(n=6)$ received a supplement of linseed oil (Lini oleum virginale, $\mathrm{n}-6 / \mathrm{n}-3$ in a ratio of 1/3, Dr. Kulich Pharma, Czech Republic) daily in the amount of $5 \mathrm{ml}$ per pig and the $\mathrm{IG}(\mathrm{n}=6)$ received inulin (Beneo, Belgium) and horse chestnut (Aesculus Hippocastanum) (extract Hippocastani extractum siccum, Calendula, Slovak Republic) daily in the

Table 1 - Composition and analyzed content of nutrients in basal HF diet (as fed basis).

\begin{tabular}{|c|c|}
\hline Items & Basal HF diet \\
\hline \multicolumn{2}{|c|}{ 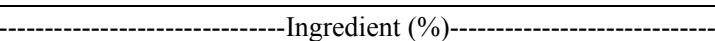 } \\
\hline Maize & 51.0 \\
\hline Soya-bean meal & 19.5 \\
\hline Barley & 10.1 \\
\hline Alfa-alfa meal & 3.5 \\
\hline Monocalcium phosphate & 1.7 \\
\hline $\mathrm{CaCO}_{3}$ & 0.3 \\
\hline Premix $^{1}$ & 0.4 \\
\hline $\mathrm{NaCl}$ & 0.4 \\
\hline Palm oil & 13.0 \\
\hline Dry matter & 90.9 \\
\hline Crude protein & 14.6 \\
\hline Crude fiber & 3.4 \\
\hline Fat & 15.6 \\
\hline Starch & 41.0 \\
\hline Total sugars & 2.6 \\
\hline Reducing sugars & 0.3 \\
\hline
\end{tabular}

${ }^{1}$ Provided the following per kilogram of diet: vitamin A, 9000IU; vitamin D3, $1500 \mathrm{IU}$; $\alpha$ - tocopherol, 35mg; vitamin B1, $1.7 \mathrm{mg}$, vitamin B2, 6mg; vitamin B6, 2.5mg; Ca-pantothenate, $15 \mathrm{mg}$; niacin, $38 \mathrm{mg}$; vitamin $\mathrm{K} 3, \quad 2 \mathrm{mg}$; biotin, $0.12 \mathrm{mg}$; cyanocobalamin, 0.03mg; choline, $156 \mathrm{mg}$; Fe, $103 \mathrm{mg} ; \mathrm{Zn}$, $116.5 \mathrm{mg} ; \mathrm{Mn}, 49.0 \mathrm{mg}$; Cu, 40mg; I, $1.2 \mathrm{mg}$; Co, 0.4mg; Se, $0.3 \mathrm{mg}$; lysine, $3.82 \mathrm{~g}$; methionine, $0.8 \mathrm{~g}$; and threonine, $1.72 \mathrm{~g}$. 
amounts of 4 and $1 \mathrm{~g}$ per pig, respectively. Inulin was extracted with hot water from a chicory root and was enriched with oligofructose. This product was composed of a mixture of long-chain inulin and short-chain oligofructose (it contained $95 \%$ fructan chains and $5 \%$ monosaccharides and disaccharides, such as fructose, glucose and sucrose). The pigs were fed twice daily at 07:00 and 16:00h in two equal doses at a daily rate of $85-90 \mathrm{~g} \mathrm{~kg}^{-0.75}$. Water was available ad libitum. To ensure the accuracy of the addition of the tested substances, they were weighed for each animal and each feeding separately and mixed with feed allowance by hand. Nutrient content in the basal HF diet was analyzed in accordance with AOAC (1990) procedures. Homogenized samples of the MLD were analyzed for FAs after extraction from the MLD samples. Lipid extraction was performed with petrol ether on an SER 148/6 (Velp Scientifica, Italy). Fatty acid composition of muscle was determined by gas chromatography (GC 6890N, Agilent Technologies, USA). The FA content was analyzed as a methylester with flameionization detection on a capillary column DB-225 (length $30 \mathrm{~m}$, ID $0.53 \mathrm{~mm}$, thickness of stationary phase 1 mikrometer) and was calculated as \% share (as relative content) from the total sum of the FAs (C6-C24).

The experimental data were subjected to an ANOVA using Statgraphic Plus 3.1 software. When the treatment effects were significant $(\mathrm{P}<0.05)$ or tended to be different $(\mathrm{P}<0.10)$, the means were separated using a Fisher's LSD procedure. Each pig was considered as an experimental unit. An analysis of covariance was conducted to evaluate the effect of the added substances on the concentration of the FAs in the MLD.

\section{RESULTS}

The effect of the addition of linseed oil, inulin and horse chestnut to a HF diet on the composition of FAs in the MLD is shown in table 2. The addition of linseed oil increased $(\mathrm{P}=0.001)$ the content of $\alpha$ - linolenic acid in the LG treatment group by 58 and $61 \%$ when compared to CG and IG treatment groups, respectively. Similarly, the content of EPA and DHA was greater $(\mathrm{P}=0.031)$ in pigs that were fed with diet with linseed oil supplements when compared to the CG and IG treatments, in which EPA and DHA were not detected. The $n-6 / n-3$ ratio in the pigs fed with the diet supplemented with linseed oil was 8.84 , which was lower $(\mathrm{P}=0.001)$ than the CG and IG treatments, which were 14.07 and 14.74 , respectively. The decrease was $31.2 \%$.
The $n-3 /$ SFA ratio increased $(\mathrm{P}=0.007)$ by $57 \%$ in the LG treatment group (0.04) when compared to the CG and IG treatment groups (0.02). Changes in the ratio of n-6/n-3 and n-3/SFA were caused by the increased content of $\alpha$ - linolenic acid, EPA and DHA. It was found that the addition of inulin and horse chestnut to the diet had no effect on the content of FAs in the MLD.

\section{DISCUSSION}

The intake of a HF diet, especially one containing a high portion of SFA (palm oil in our study), is characterized by its negative effect on the body (FIORENTINI et al., 2015; LAUGERETTE et al., 2015). Dietary manipulations at the beginning of the food chain may increase the content of n-3 FA and mitigate the negative effect in humans with a HF diet. Pork is considered to be a main source of SFA, but the content of FAs can be changed by suitable dietary manipulations to pigs nutrition (ČERVEK et al., 2011). Linseed is a rich source of n-3 FA, particularly of $\alpha$ - linolenic acid (NITRAYOVÁ et al., 2014) from which n-3 FA with longer chain, EPA and DHA, are metabolized. The supplementation of linseed oil into the diet of pigs increased the content of $\alpha$ - linolenic acid in meat (ČERVEK et al., 2011). In the present study, the positive effect of the addition of linseed oil into a HF diet on the content of $\alpha$ - linolenic acid, EPA and DHA in the MLD was confirmed. Similarly, in other researches, the addition of linseed oil into the diet of pigs increased the concentration of n-3 FA in the body (KASTEL' et al., 2007). Linseed oil supplemented into a HF diet decreased a ratio of $n-6 / n-3$ in the MLD when compared with pigs fed a diet without supplemented linseed oil. Similar results were also reported in other studies (ČERVEK et al., 2011; HAUGH et al., 2012). Despite this, the ratio of $n-6 / n-3$ was higher than the results reported by OKROUHLÁ et al. (2013) who also studied pigs fed with a diet with addition of linseed. The difference between studies was caused by the fact that the content of n-3 in our study was only increased slightly. Addition of linseed oil into the diets resulted in an increase in the n-3/SFA ratio. Similar results were also reported by NÜRNBERG et al. (2011). The $n-6 / n-3$ ratio decreased and the $n-3 /$ SFA ratio increased as a result of the increased n-3 content in the MLD.

The microbial population influences the metabolism of cells in adipose tissues (DELZENNE et al., 2011). The metabolic activity of the enteric microbiota and the dietary manipulation thereof 
Table 2 - Effect of diet on the FA composition in musculus Longissimus dorsi (\%).

\begin{tabular}{|c|c|c|c|c|c|}
\hline \multirow{2}{*}{ Fatty acids } & \multicolumn{3}{|c|}{-Treatments ${ }^{1}-$} & \multirow{2}{*}{ SEM } & \multirow{2}{*}{ P-value } \\
\hline & $\mathrm{CG}$ & LG & IG & & \\
\hline C10:0 (Capric acid) & 0.04 & 0.05 & 0.04 & $<0.01$ & 0.980 \\
\hline C12:0 (Lauric acid) & 0.06 & 0.06 & 0.05 & $<0.01$ & 0.107 \\
\hline C14:0 (Myristic acid) & 0.96 & 0.88 & 0.83 & 0.05 & 0.269 \\
\hline C16:0 (Palmitic acid) & 24.23 & 23.91 & 22.85 & 1.05 & 0.627 \\
\hline C6:1 n-7 (Palm-oil acid) & 2.13 & 1.98 & 1.89 & 0.14 & 0.535 \\
\hline C18:0 (Stearic acid) & 9.51 & 9.76 & 10.5 & 0.53 & 0.468 \\
\hline C18:1 n-9 (Oleic acid) & 51.96 & 50.88 & 52.44 & 1.37 & 0.637 \\
\hline C18:2 n-6 (Linoleic acid) & 10.03 & 10.77 & 10.2 & 0.29 & 0.172 \\
\hline C18:3 n-3 ( $\alpha$ - Linolenic acid $)$ & $0.73^{\mathrm{a}}$ & $1.15^{\mathrm{b}}$ & $0.71^{\mathrm{a}}$ & 0.04 & 0.001 \\
\hline C20:0 (Arachidic acid) & 0.14 & 0.15 & 0.18 & 0.01 & 0.135 \\
\hline C20:4 n-6 (Arachidonic acid) & 0.20 & 0.30 & 0.29 & 0.05 & 0.473 \\
\hline C20:5 n-3 (Eicosapentaenoic acid) & - & 0.03 & - & 0.01 & 0.031 \\
\hline C22:0 (Behenic acid) & 0.01 & 0.01 & 0.01 & $<0.01$ & 0.620 \\
\hline C22:1 n-9 (Erucic acid) & 0.01 & 0.00 & 0.01 & $<0.01$ & 0.450 \\
\hline C22:6 n-3 (Docosahexaenoic acid) & - & 0.07 & - & 0.05 & 0.013 \\
\hline$\Sigma \mathrm{SFA}^{2}$ & 34.90 & 34.82 & 34.46 & 1.39 & 0.950 \\
\hline$\Sigma \mathrm{n}-6$ & 10.23 & 11.02 & 10.49 & 0.20 & 0.315 \\
\hline$\Sigma \mathrm{n}-3$ & $0.73^{\mathrm{a}}$ & $1.25^{\mathrm{b}}$ & $0.71^{\mathrm{a}}$ & 0.04 & 0.001 \\
\hline$\Sigma$ MUFA & 54.09 & 52.44 & 54.34 & 1.39 & 0.648 \\
\hline$\Sigma$ PUFA & $10.96^{\mathrm{a}}$ & $12.27^{\mathrm{b}}$ & $11.2^{\mathrm{ab}}$ & 0.35 & 0.087 \\
\hline MUFA/SFA & 1.55 & 1.51 & 1.58 & 0.16 & 0.562 \\
\hline PUFA/SFA & 0.31 & 0.35 & 0.33 & 0.18 & 0.359 \\
\hline$n-6 / S F A$ & 0.29 & 0.32 & 0.31 & 0.16 & 0.561 \\
\hline$n-3 / S F A$ & $0.02^{\mathrm{a}}$ & $0.04^{\mathrm{b}}$ & $0.02^{\mathrm{a}}$ & $<0.01$ & 0.007 \\
\hline n-6 PUFA / n-3 PUFA & $14.07^{\mathrm{a}}$ & $8.84^{\mathrm{b}}$ & $14.74^{\mathrm{a}}$ & 0.15 & 0.001 \\
\hline
\end{tabular}

${ }^{1} \mathrm{CG}$ - control group fed HF basal diet, LG - fed basal HF diet supplemented with linseed oil in daily amount $5 \mathrm{ml} \mathrm{pig}^{-1}$, IG - fed basal HF diet supplemented with inulin in daily amount $4 \mathrm{~g} \mathrm{pig}^{-1}+$ horse chestnut in daily amount $1 \mathrm{~g} \mathrm{pig}^{-1}$.

${ }^{\mathrm{ab}}$ means in raw are significantly different.

represent a realistic target for the modification of the FA composition in host tissues. WALL et al. (2009) reported that the oral administration of bifidobacteria increased the concentrations of EPA and DHA in the adipose tissue in mice. Because prebiotics have a positive effect on the intestinal microflora of the body (ROBERFROID, 2007), they can alter the metabolism of fats in the host tissue. For example, the prebiotic mannanoligosaccharide had a positive effect on lipid metabolism in terms of reducing serum cholesterol and abdominal fat in chickens (KANNAN et al., 2005). Additionally, inulin lowered blood lipids in human studies (BALCAZAR-MUNOZ et al., 2003; LETEXIER et al., 2003).

Although, information about the effect of prebiotics on the FA content in tissues is limited. DEWULF et al. (2011) reported that inulin-type fructans supplemented to a HF diet $(31.6 \%$ lard; $3.2 \%$ soybean oil) did not modify the FA pattern in mice. In chickens, the addition of inulin in a diet containing sunflower oil increased the content of PUFA due to increase in $\alpha$ - linolenic acid and the decreased SFA content in the fat and muscle tissues, but this effect was not observed when palm oil was used (VELASCO et al., 2010). Similarly, in the present study, when inulin with horse chestnut was added into the HF diet, there was no impact on the composition of the FAs in the MLD. It can be speculated that it was probably a result of the low dose of the tested prebiotics and a subsequent low efficiency to suppress the negative effect of the HF palm oil diet in changes of composition of the gut microbiota (DELZENNE et al., 2011). Alternatively, the null result could be due to the fact that the effect of the prebiotics on the changes to the FA profile in the host tissue depends on the saturation of the dietary fat (VELASCO et al., 2010). In the study by VELASCO et al. (2010), the content of SFA in the palm oil diet was 3.4 times greater than in the sunflower diet, and in the study of DEWULF et al. 
(2011), the lard in the diet increased the content of SFA as well (MATTSON \& LUTTON, 1958).

As mentioned above, the common diet contains a high content of saturated and a low content of unsaturated FAs. The required content and ratio of FAs in the human body can be achieved by changing the FA content in consumed products (HAUGH et al., 2012). The addition of linseed oil into the diet of pigs is a suitable way to increase the content of PUFA in the food chain of a consumer (ČERVEK et al., 2011), as well as, to suppress the negative effect of a HF diet in terms of the n-3 FA intake and the reduction of the $n-6 / n-3$ ratio, which cannot be said about the addition of inulin and horse chestnut to the HF palm oil diet.

\section{CONCLUSION}

The supplementation of linseed oil into a HF diet increased the content of $\alpha$ - linolenic acid, EPA and DHA in the MLD, which resulted in a reduction of the $n-6 / n-3$ ratio in the MLD of pigs and; therefore, is a suitable way to increase the content of PUFA in pork meat and reduce the effect of a HF diet. In the present study, the addition of inulin and horse chestnut had no effect on the FA profile in the MLD.

\section{BIOETHICS AND BIOSSECURITY COMMITTEE APPROVAL}

All of the experimental procedures were reviewed and approved by the Animal Care Committee of the Research Institute of Animal Production Nitra.

\section{ACKNOWLEDGMENTS}

This article was written during the realization of the project "ZDRAVIE no. 26220220176" supported by the Operational Program Research and Development funded from the European Regional Development Fund.

\section{REFERENCES}

AOAC (ASSOCIATION OF OFFICIAL ANALYTICAL CHEMISTS). Official methods of analysis. 15.ed. Arlington, 1990. 771p.

BALCAZAR-MUNOZ, B.R. et al. Effect of oral inulin administration on lipid profile and insulin sensitivity in dyslipidemic obese subjects. Revista médica de Chile, v.131, p.597-604, 2003. Available from: <http://dx.doi.org/10.4067/ S0034-98872003000600002>. Accessed: Jun. 20, 2015. doi: 10.4067/S0034-98872003000600002.

BEE, G. et al. Effects of two supplementation levels of linseed combined with CLA or tallow on meat quality traits and fatty acid profile of adipose and different muscle tissues in slaughter pigs.
Animal, v.2, p.800-801, 2008. Available from: <http://dx.doi. org/10.1017/S175173110800181X>. Accessed: Oct. 19, 2014. doi: $10.1017 / \mathrm{S} 175173110800181 \mathrm{X}$

ČERVEK. M. et al. Effect of linseed supplementation on carcass, meat quality and fatty acid composition in pigs. Agriculturae Conspectus Scientificus, v.76, p.183-186, 2011. Available from: <http://www.agr.unizg.hr/smotra/pdf_76/acs76_31.pdf>. Accessed: Sept. 18, 2013

DELZENNE, N.M. et al. Targeting gut microbiota in obesity: effects of prebiotics and probiotics. Nature Reviews Endocrinology, v.7, p.639-646, 2011. Available from: <http:// dx.doi.org/10.1038/nrendo.2011.126>. Accessed: Jun. 20, 2015. doi: $10.1038 /$ nrendo.2011.126.

DEWULF, E.M. et al. Inulin-type fructans with prebiotic properties counteract GPR43 overexpression and PPAR $\gamma$ related adipogenesis in the white adipose tissue of highfat diet-fed mice. Journal of Nutritional Biochemistry, v.22, p.712-722, 2011. Available from: <http://dx.doi. org/10.1016/j.jnutbio.2010.05.009>. Accessed: Jun. 21, 2015. doi: $10.1016 /$ j.jnutbio.2010.05.009.

FIORENTINI, G. et al. Lipid sources with different fatty acid profile alter the fatty acid profile and quality of beef from confined nellore steers. Asian-Australasian Journal of Animal Sciences, v.28, p.976-986, 2015. Available from: $<\mathrm{http}$ ://dx.doi.org/10.5713/ajas.14.0893>. Accessed: Oct. 15, 2014. doi: 10.5713/ajas.14.0893.

HAUGH, A. et al. Increased EPA levels in serum phospholipids of humans after four weeks daily ingestion of one portion chicken fed linseed and rapeseed oil. Lipids in Health and Disease, v.11, p.1-12, 2012. Available from: $<\mathrm{http} / / \mathrm{dx}$.doi.org/10.1186/1476-511X-11-104> Accessed: Nov. 22, 2014. doi:10.1186/1476-511X-11-104.

KANNAN, M. et al. Influence of prebiotics supplementation on lipid profile of broilers. International Journal of Poultry Science, v.4, p.994-997, 2005. Available from: <http://www.pjbs. org/ijps/fin501.pdf $>$. Accessed: Jun. 15, 2015.

KASTEL', R. et al. The effect of probiotics potentiated with polyunsaturated fatty acids on the digestive tract of germ-free piglets. Veterinary Medicine-Czech, v.52, p.63-68, 2007. Available from: <http://www.vri.cz/docs/vetmed/52-2-63. pdf $>$. Accessed: Nov. 22, 2014.

LAUGERETTE, F. et al. Oil composition of high-fat diet affects metabolic inflammation differently in connection with endotoxin receptors in mice. American Journal of Physiology Endocrinology and Metabolism, v.302, p.E374-E386, 2012. Available from: <http://dx.doi. org/10.1152/ajpendo.00314.2011>. Accessed: Apr. 25, 2015. doi: 10.1152/ajpendo.00314.2011.

LETEXIER, D.F. et al. Addition of inulin to a moderately high-carbohydrate diet reduces hepatic lipogenesis and plasma triacylglycerol concentrations in humans. American Journal of Clinical Nutrition, v.77, p.559-564, 2003. Available from: <http:// ajcn.nutrition.org/content/77/3/559.long $>$. Accessed: Apr. 25, 2015.

MATTSON, F.H.; LUTTON, E.S. The specific distribution of fa in the glycerides of animal and vegetable fats. Journal of Biological Chemistry, v.233, p.868-871, 1958. Available from: $<$ http://www. jbc.org/content/233/4/868.full.pdf $>$. Accessed: May 4, 2015. 
NITRAYOVÁ, S. et al. Amino acids and fatty acids profile of chia (salvia hispanica 1.) and flax (Linum usitatissimum 1.) seed. Scientific Journal of Food Industry, v.8, p.72-76, 2014. Available from: <http://dx.doi.org/10.5219/332>. Accessed: Nov. 20, 2014. doi: $10.5219 / 332$.

NÜRNBERG, K.G. et al. Effect of extruded linseed on growth and lipids of muscle and back fat in pigs. Fleischwirtschaft, v.91, p.88-92, 2011. Available from: <http://www. fleischwirtschaft.de/service/fleischwirtschaft/abstracts/ Fleischwirtschaft+91/Wirkung+von+extrudierter+Leinsaat+in + der+Schweinemast $>$. Accessed: Sept. 20, 2014.

OKROUHLÁ, M. et al. Effect of dietary linseed supplementation on the performance, meat quality, and fatty acid profile of pigs. Czech Journal of Animal Science, v.58, p.279-288, 2013. Available from: $<$ http://www.agriculturejournals.cz/publicFiles/93103.pdf $>$. Accessed: Oct. 8, 2014.

ROBERFROID, M. Prebiotics: the concept revisited. Journal of Nutrition, v.137, p.830S-837S, 2007. Available from: <http:// jn.nutrition.org/content/137/3/830S.long>. Accessed: Oct. 8, 2014.

RUSSO, G.L. Dietary n-6 and n-3 polyunsaturated FA: from biochemistry to clinical implications in cardiovascular prevention. Biochemical Pharmacology, v.77, p.937- 946, 2009. Available from: <http://dx.doi.org/10.1016/j.bcp.2008.10.020>. Accessed: Nov. 20, 2014. doi: 10.1016/j.bcp.2008.10.020.
SIMOPOULOS, A.P. Omega-3-fatty-acids in health and disease and in growth and development. American Journal of Clinical Nutrition, v.54, p.438-463, 1991. Available from: <http://www.ajcn.nutrition.org/ content/54/3/438.full.pdf + html $>$. Accessed: Nov. 22, 2014.

SZABADOSOVA, V. et al. Effect of horse chestnut and inulin as single supplements or in combination on chemically induced colon cancer in rats. Veterinary Medicine-Czech, v.58, p.491-499, 2013. Available from: <http://www.vri.cz/docs/vetmed/58-9-491. pdf>. Accessed: Nov. 20, 2014.

VELASCO, S. et al. Effect of inulin supplementation and dietary fat source on performance, blood serum metabolites, liver lipids, abdominal fat deposition, and tissue fatty acid composition in broiler chickens. Poultry Science, v.89, p.1651-1662, 2010. Available from: <http://dx.doi.org/10.3382/ps.2010-00687>. Accessed: Jun. 20, 2015. doi: 10.3382/ps.2010-00687.

WALL, R. et al. Metabolic activity of the enteric microbiota influences the fatty acid composition of murine and porcine liver and adipose tissues. American Journal of Clinical Nutrition, v.89, p.1393-401, 2009. Available from: http://ajcn.nutrition.org/ content/89/5/1393. full.pdf >. Accessed: Apr. 18, 2015.

WILLIARD, D.E. Docosahexaenoic acid synthesis from n-3 PUFA in differentiated rat brain astrocytes. Journal of Lipid Research, v.42, p.1368-1376, 2001. Available from: <http://www.jlr.org/ content/42/9/1368.full.pdf >. Accessed: Nov. 25, 2014. 